\title{
The influence of post-2008 legislation on an acquisition that turned hostile: A South African case study
}

\author{
A.K. Biggs, C.B. Scheepers* and M.M. Botha \\ Biggs and Scheepers from: Gordon Institute of Business Science, University Pretoria, P O Box 787602, Sandton, 2146, South \\ Africa; Botha from Department Mercantile Law, Faculty Law, University Pretoria, Private bag X20, Hatfield, 0028, South Africa
}

*To whom all correspondence should be addressed

scheepersc@gibs.co.za

\begin{abstract}
Hostile acquisitions have a significant impact on managers and employees. The possibility of an acquisition creates uncertainty and when the acquisition turns hostile it is even more disruptive to the target organisation. Also, negative perceptions are often created in the media about the acquirer that influence employees' attitudes in the target organisation. Processes to successfully integrate the acquirer and target organisations are impacted by these antagonistic pre-acquisition circumstances.
\end{abstract}

\begin{abstract}
The Companies Act (no.71 of 2008) created opportunities for shareholders to hold an acquired company's management accountable for financial performance and the researchers set out to investigate how the intent of the new legislation played out in practice, by studying an acquisition that turned hostile. The single case study research methodology revealed the manoeuvring of both the acquiring and acquired companies which utilised the mechanisms available to them through the new legislative, regulatory and corporate governance landscapes. The researchers provide an extensive review of the relevant mergers and acquisitions' literature, as well as influence of the international legislative environment on the current local regulations. These regulations in turn, inform corporate governance and ultimately board behaviours. The researchers conducted qualitative interviews with key role players as well as legal and financial experts. The findings of the thematic analysis and triangulation process, informed a conceptual frame of three episodes.
\end{abstract}

\section{Introduction}

Acquisitions are often used as strategic choice to rapidly expand or diversify (Galpin \& Herndon, 2007; Hitt, Ireland \& Hoskisson, 2007; Marks \& Mirvis, 2010; Sherman \& Hart, 2006). Unfortunately, "approximately $70 \%$ fail and scholars from different disciplines and perspectives have tried to find the root of the problem and solve the acquisition puzzle" (Vasilaki, 2009: 3). Over the last two decades, studies on post-acquisition integration processes and organisational design of the new entities have progressed to become a focal point in academic research. These studies reveal contingencies that existed prior to the acquisition, for example, motives behind the acquisition and relatedness, as important variables in the success of achieving synergies and espoused monetary value in the post-integration phase (Birkinshaw, Bresman \& Hákanson, 2000). These findings suggest more studies are required into pre-acquisition phases that could influence post-acquisition success. In the case of hostile acquisitions in particular, negative perceptions about the motives behind the acquisition increase, leading to resistance and making it even more difficult to achieve synergies. A deeper understanding of conditions that turn acquisitions antagonistic is therefore essential.

Relevant academic literature on the pre-acquisition phase includes, for example, the classic Efficiency Theory of Trautwein (1990), which describes acquisition motives as synergistic: gaining efficiencies by combining the operations of two companies. Another motive, revealed by the seminal work of Martin and McConnell (1991), is to improve operating strategies by replacing the target's senior management, the so-called Disciplinary Theory of acquisitions. The Agency Theory suggests that acquisitions occur because they enhance the welfare of the acquiring organisation's management, at the expense of their shareholders (Wright, Kroll \& Elenkov, 2002). It relates to the Hubris Theory, in which these managers declare that the target company would be more successful under their management, and where the sources of hubris include narcissism, and series of succession or exemption from the rules (Seth, Song \& Pettit, 2002). Motives for acquisitions, and the degree of relatedness of the two entities, also lead to particular types of acquisitions. These include vertical acquisitions, where the two companies are in the same industry, but often operating at a different stage of the production chain; and horizontal acquisitions, where two competitors combine to increase market share. In contrast, a conglomerate acquisition occurs when the two organisations are completely unrelated and are often said to lack industrial logic (Gaughan, 2007). In mergers and acquisitions (M\&A) academic studies, a negative relationship has been reported between the unrelatedness of the two entities and the acquisition performance, as represented by the Process School of thought of Larsson and Finkelstein (1999). 
Case study research methodology was utilised in this exploration. The investigation required an inductive approach to acquire qualitative insight into the processes underlying the phenomenon and draw inferences from it (Yin, 2009, 2015). Case studies are particularly suited to new research areas where causality is still being established and which are therefore primarily used to develop new theories (Barratt, Choi \& Li, 2011). They represent a constructivist ontological approach of social phenomena being continually constructed by social actors (Creswell, 2013); in this case, the acquisition process is continuous and involves a pre-acquisition phase, deal phase and post-acquisition integration phase. An extensive review of academic literature and media releases about this acquisition was conducted, as well as a review of the international legislative environment and its influence on the current local regulations. The Johannesburg Stock Exchange's (JSE's) regulatory requirements for announcements provided a valuable source of factual data from which an accurate timeline of events was constructed. This account of the run of events was then used as a departure point for a number of qualitative interviews of key role players in the saga, as well as legal and financial specialists. A process of triangulation of data from these interviews, according to the archival records, was then undertaken and inferences drawn to investigate the research question and subquestions (see below). The paper offers these inferences and implications as a contribution to the deeper understanding of the complex intricacies regarding hostile acquisitions and to add to the existing body of knowledge.

The scarcity of hostile acquisitions in South Africa created unique research opportunities for the study, yet created the dilemma of ensuring anonymity and confidentiality. The identity of the companies, the shareholding, the industry and financial information are therefore not revealed. It is important to note that the target company had reported a decrease in market capitalisation. This financial loss meant this was a company with assets, but in distress due to a number of acquisitions and investments that had proved unwise.

This study investigated three sub-questions to the main research question, "What was the influence of post-2008 legislation and accompanying regulations and governance policies on a particular acquisition that turned hostile?" as follows:

1. What was the run of events in the proceedings of the preacquisition phase?

2. How did the context of new regulations, and governance policies alongside the new legislation, play a role in the acquisition turning hostile?

3. Which of the current acquisition theories on motives and relatedness were applicable in the pre-acquisition phase of this particular case study?

\section{Literature review}

\section{Setting the scene: The Companies Act 71 of 2008}

The majority of existing research centres around developed countries' anti-takeover provisions (Armour \& Skeel, 2007; Blackshaw, 2014; DePamphilis, 2012; Myles \& Young, 2014; Sinha, 2004) and there is a lack of focus on emerging markets (Demidova, 2007). Nonetheless, the history and incidence of hostile takeovers in developed countries provide valuable input to identify trends and influencers. Further, the jurisdiction under review is South Africa, where the judicial system is mainly influenced by the shareholder-orientated takeover regulations of the $\mathrm{UK}$, in contrast to the management-orientated takeover regulations in the USA (Dignam, 2007). Moreover, hostile takeovers in South Africa have shown a tendency to fail (Whate, 2013) and are usually not the preferred mechanism for effecting an acquisition (Douglas \& Oppenheim, 2013). As a result, the incidence of hostile takeovers is limited.

Chapter 5 of the 2008 Companies Act of the Republic of South Africa applies to 'fundamental transactions' and takeovers. The Act, however, does not define the concept 'fundamental transaction' and instead provides for three types of fundamental transactions in Part A of Chapter 5 (Delport, 2011; Cassim, Cassim, Cassim, Jooste, Shev \& Yeats, 2012). Fundamental transactions consist of the following:

1. Proposals to dispose of substantially all assets or undertakings (section 112);

2. Amalgamations and mergers (section 113); and

3. Scheme of arrangement (section 114).

Prior to the 2008 Companies Act, the takeover regime in South Africa was governed by the Securities Regulation Panel Code and the Securities Regulation Panel Rules of the Companies Act 61 of 1973. Section 117 to 127 of the 2008 Act now contains provisions regarding takeovers. The Takeover Regulations replaced both the Securities Regulation Panel Code and the Securities Regulation Panel Rules of the 1973 Act.

In terms of South Africa's regulatory environment, all listed companies on the JSE are required, per the JSE Listing Requirements, to apply the principles of governance as set out in the King Code for Governance Principles for South Africa 2009 (King III) that released a practice note in October 2009, specifically setting out generally accepted principles of good governance for fundamental and affected transactions, intended to supplement the Takeover Regulations Panel (du Plessis, 2009; Institute of Directors in Southern Africa, 2009a). These Principles include one stating that during affected transactions, director fiduciary duties are to be expanded to include the general body of the company's relevant shareholders and shareholders of different classes, types and rights to share should be treated comparably (Douglas \& Oppenheim, 2012, 2013; du Plessis, 2009). Legislative and regulatory frameworks form the environment within which corporate governance of companies takes place 
(Ryngaert \& Scholten, 2010). The Takeover Regulation Panel (TRP) must regulate any affected transaction in respect of regulated companies. The latter will take place in accordance with Parts B and C of Chapter 5 of the 2008 Act and the Takeover Regulations (which were published in April 2011) (Cassim et al., 2012; Delport, 2011). The law and application thereof relating to takeovers, "hinges on certain key definitions contained in the Act" (Cassim et al., 2012: 732). These definitions are closely examined below.

\section{Affected transaction}

The definitions of "affected transaction" relevant to this study are in terms of section 117(1)(c) of the 2008 Act:

- a scheme of arrangement between a regulated company and its shareholders, as contemplated in section 114, subject to section 118(3) (iii);

- the acquisition of, or announced intention to acquire, a beneficial interest in any voting securities of a regulated company to the extent and in the circumstances contemplated in section 122(1) (iv);

- the announced intention to acquire a beneficial interest in the remaining voting securities of a regulated company not already held by a person or persons acting in concert (v);

\section{Offer}

In terms of section 117(1)(f) 'offer' means a proposal of any sort, including a partial offer, which if accepted, will result in an affected transaction, other than such a transaction that is exempted in terms of section 118(3).

\section{Acting in concert}

Section 117(1)(b) defines 'act in concert' as any action pursuant to an agreement between or among two or more persons, in terms of which any of them co-operate for the purpose of entering into or proposing an affected transaction or offer (see also SRP v MGX Holdings Ltd, unreported case no $16026 / 03$ of the High Court Witwatersrand Local Division in this regard). Regulation 84 provides that the following persons are presumed to have 'acted in concert' with another:

- a company with its directors; a company with any company controlled by one or more of its directors; a company with any trust of which any one or more of its directors is a beneficiary or trustee; and

- any of the company's pension, provident or benefit funds and share incentive schemes with one another.

\section{Regulation of affected transactions and offers under the 2008 Act}

Section 121 applies the take-over provisions of the 2008 Act to affected transactions and provides that any person making an offer must comply with all the reporting or approval requirements as set out in Part B or $\mathrm{C}$ or the Takeover
Regulations, except to the extent that the TRP has granted that person an exemption from any such requirement, and must not be given the effect to an affected transaction unless the TRP (i) issues a compliance certificate with respect to the transaction; or (ii) granted exemption for that transaction.

\section{Definition of a takeover}

Takeovers "focus on the effect that a transaction has and whether it results in the acquisition, consolidation or change of control" and occurs when "an individual or a company, through a transaction, acquires control (or takes over) the assets or management of another company" (Whate, 2013: 4). The Takeover Regulations do not explicitly provide for a distinction between friendly and hostile takeovers, yet this distinction is evident from the provisions (Whate, 2013: 6). A friendly takeover is also referred to as a 'negotiated takeover' (Matsaneng, 2010: 88) and is where the "acquirer has approached the board of the target company prior to making the formal bid to the shareholders of the said company" and if the board agrees with the offer it is then recommended to the shareholders or remains neutral (Whate, 2013: 7; Levitt \& Bee, 2009: 41).

A hostile take-over in contrast, is referred to as an unnegotiated takeover (Matsaneng, 2010: 87). Demidova (2007) defines the term hostile takeover as an attempt to obtain control over the financial and business activity, or assets of a target company against the resistance of management or key participants in the company. Hostile bids are unsolicited offers that challenge the strategic direction and leadership of the company (Pearce \& Robinson, 2004).

\section{Legislative environment and hostile takeovers}

Globally, markets can be classified as either liquid or illiquid. Liquid markets, also known as the Market Model, are those in which shares are easily traded and investors discipline bad managers by selling their shares, as in the United States of America (USA) (DePamphilis, 2012). An illiquid market, or Control Market, is one in which investors discipline poor performing management through large block shareholders of the organisation. Hostile takeover activity is more commonly encountered in these Control Markets in the United Kingdom (UK), as well as across Europe and the Commonwealth (DePamphilis, 2012). As a result, jurisdiction-specific takeover frameworks developed which created large discrepancies in a comparison of European countries' hostile takeover environments (Myles \& Young, 2014). Burkart, Gromb, Mueller and Panunzi (2014) found that takeover outcomes are more efficient in countries with stronger legal investor protection and their incidence is significantly higher in the UK than in the USA (Sinha, 2004).

The researchers have established two opposing approaches to hostile takeovers as represented by legislative environments from either side of the Atlantic. The USA model fundamentally protects the management of an organisation, assuming that shareholders are investors looking to make a return on investment, but having limited engagement with the 
operations of the organisation (Armour \& Skeel, 2007; Bernstein, 2014; Dignam, 2007). The UK system, on the other hand, protects the shareholders of the company, with legislation restricting the powers of management, especially in situations where potential offers might be proposed (Armour \& Skeel, 2007; Bates, Becher \& Lemmon, 2008; Bertrand \& Mullainathan, 2003; Blackshaw, 2014; Dignam, 2007).

The new Companies Act 2008 brought about a much-needed modernisation of the South African corporate law framework in line with international trends. The new act dramatically decreased the courts' role in takeovers and fundamental transactions (Douglas \& Oppenheim, 2012, 2013; du Plessis, 2009). The Scheme of Arrangement (SoA) governed by section 114 of the Companies Act 2008 is the most commonly used method of obtaining control of a company in an offer recommended by the board to the shareholders. An important issue in scholarly research is the effect of the legal setting on regulations and subsequent corporate governance (Ryngaert \& Scholten, 2010).

\section{Regulatory requirements with regard to hostile takeovers}

Hostile takeovers in South Africa are largely regulated by the Johannesburg Stock Exchange (JSE) Listings Requirements and the Exchange Control Regulations (Douglas \& Oppenheim, 2012). South African takeover regulations are mainly based on a market-led approach, similar to the UK City Code on Takeovers and Mergers. The most significant difference is that the UK code is a self-regulated code, as opposed to the South African one, which is a statutory code enforceable in court. With the introduction of the new corporate legislation, there is renewed focus on whether the market for corporate control (Dignam, 2007) within South Africa has reached a level that supports the market-led disciplinary process of a hostile takeover, to keep management focused on the realisation of shareholder value.

The UK approach is driven largely by the significant role played by institutional shareholders. Today, the UK operates what is known as an enlightened shareholder value system of corporate governance (Hopkins \& Corte, 2014). The recent impetus for increased shareholder activism in the UK stems from the global financial crisis. The difference between the US and UK approaches highlight its relevance to emerging markets around the world, for example, traditionally a topdown, mandatory regulatory environment, enforced through the court systems, had been considered the only way to regulate corporate transactions (Armour \& Skeel, 2007). However the success of the UK's self-regulated takeover regime suggests that this approach may be flawed (Dignam, 2007). The US approach requires an effective governmental regulator and an efficient court system, however, both of which are usually non-existent in an emerging market environment (Armour \& Skeel, 2007). The principle of neutralising management while a bid is in progress has been adopted in takeover regulations and has formed a core part of the European Union takeovers directive and the development of takeover regulations for Australia, Switzerland, Italy, Portugal, Austria, Spain, Hong Kong, New Zealand, Ireland, Malaysia, Singapore and South Africa (Dignam, 2007).

\section{Corporate governance mechanisms in hostile takeovers}

Corporate governance is a broad concept and there is no generally accepted definition. Corporate governance has been defined as: "the collection of law and practices, grounded in fiduciary duties and their application, that regulates the conduct of those in control of the corporation, and the means through which a variety of countries provide legal basis for corporations while preserving, to some extent, authority to control abuses of these business organisations" (Aka, 2007: 238). DePamphilis (2012) defines corporate governance as the monitoring of those factors internal and external to the firm that interact to protect the rights of the corporate stakeholders, with the ultimate purpose defined as holding accountable those with the ability to make the decisions. Corporate governance, moreover, mainly involves the establishment of structures and processes, with appropriate checks and balances, that enable directors to discharge their legal responsibilities and oversee compliance with legislation (Davis \& Le Roux, 2012: 307).

Section 119(1)(c) of the 2008 Companies Act provides that one of the aims of the TRP is "to prevent actions by a regulated company designed to impede, frustrate or defeat an offer, or the making of fair and informed decisions by holders of that company's securities." The board of directors of a regulated company is subject to certain restrictions which are triggered once it has received a bona fide offer or believes that such a bona fide offer might be imminent (Cassim et al., 2012: 739; Delport, 2011: 138). Section 126 provides that the board of directors must not take any action in relation to the affairs of the company that could effectively result in a bona fide offer being frustrated or the holders of relevant securities being denied an opportunity to decide on its merits. It further provides that the board must not: (i) issue any authorised by unissued securities; (ii) issue or grant options in respect of any unissued securities; (iii) authorise, issue or permit the authorisation or issue of, any securities carrying rights of conversion into securities or subscription for other securities; (iv) sell, dispose of, or acquire, or agree to sell, dispose of or acquire, assets of a material amount, except in the ordinary course of business; (v) enter into contracts otherwise than in the ordinary course of business; or (vi) make a distribution that is abnormal regarding timing and amount (Section 126 of the 2008 Companies Act). Section 126 was designed to achieve the objective as set out in section 119 of the Companies Act 2008 and regulates the actions of the board of directors once an offer is imminent or has been received by the regulated company (Stein \& Everingham, 2011: 332; Whate, 2013: 18). Section 126 consists of a 'catch-all' clause (Stein \& Everingham, 2011: 333) and specified prohibited actions (section 126(1)(a)-(g) of the Companies Act (2008)). The duty imposed by the frustration provision in section 126 is two-fold (Sutherland, 2012: 96): 
"There is the positive duty to inform shareholders of the offer and the negative duty not to frustrate the bid. Flowing from the positive duty to inform shareholders is the fact that directors are permitted to offer advice or make recommendations and provide the information on which the recommendation or advice is based. This is to safeguard against shareholders selling their shares at an undervalue. The negative duty not to frustrate a bid flows from the fiduciary duty to act in the best interest of the company. It has been held that it is a breach of this duty to prevent shareholders from deciding on the merits of the offer whether they would like to accept or reject the bid" (Whate, 2013: 19-20).

Directors and managers tend to oppose hostile bids as they involve inherent risks (Nickig, 2011: 22; Whate, 2013: 8): the acquirer "will not be able to undertake a complete due diligence of the target company and as a result financial institutions will be reluctant to finance the takeover as the extent of the liabilities of the target company are unknown" (Levitt \& Bee, 2009: 8; Whate, 2013: 8). The actions listed above in section $126(1)(\mathrm{a})-(\mathrm{g})$ may not be taken without prior approval of the TRP, and the approval of the holders of the relevant securities, or in terms of a pre-existing obligation or agreement.

The researchers established two distinct perspectives on corporate governance during takeovers. Becker-Blease (2011), Chakraborty, Rzakhanov and Sheikh (2014), Gaughan (2007), Merrett and Houghton (1999) as well as Ryngaert and Scholten (2010) emphasise, for example, that managers exploit governance structures by establishing protection afforded by takeover provisions to enjoy privileges, build empires or shirk responsibilities. Shareholders excluded from these acquisition decisions experience reduced wealth when managers take actions to deter attempts to change control of the company, or when managers seek to maintain their positions through the use of active and preventative corporate governance defences. Pearce and Robinson (2004) highlight that rejecting the initial offer may well be management's attempt to secure its own position, at the expense of wealth gains by its shareholder body.

Conversely, the shareholder interest perspective stresses that takeover provisions generally benefit shareholders by enabling directors to avoid having to invest time and effort into under-priced acquisition attempts, allowing them to focus on extracting the highest takeover premium and better align managers' investment horizons to those of long-term shareholders. In fact, shareholder wealth rises when management takes action to prevent changes in control (Gaughan, 2007; Becker-Blease, 2011). Pearce and Robinson (2004) point out that rejecting the initial offer may force the offeror to sweeten the offer.

While shareholder activism was initially almost universally seen in a negative light, the perception has shifted to the point where shareholder engagement has become a market expectation, especially when it comes to shareholders expressing their views on corporate strategy (Hopkins \& Corte, 2014). Decisions relating to the strategic issue of change in control are the responsibility of the owners of the business, but these decisions are often abdicated to the executive group as the dispersed shareholder body lacks knowledge of, and interest in, the business' daily operations. Executives often exercise significant autonomy when making decisions that directly impact the shareholders' interest in maximising wealth (Clarke \& Brennan, 1990; Myles \& Young, 2014; Pearce \& Robinson, 2004; Ryngaert \& Scholten, 2010). Mohamed (2010) and Olaerts and Schwarz (2012) caution, however, that shareholder democracy and subsequent activism leads to opportunistic behaviour by influential shareholders with personal interests. On the other hand, the freedom of shareholders to accept a takeover bid without board interference is regarded as an important element of a well-functioning system of corporate governance (Schoenberg \& Thornton, 2006). Schoenberg and Thornton's (2006) statistical analysis showed that white knights (friendly acquirers, who join the acquisition contest when the target is already under siege by a hostile bidder) and management buy-outs were the most effective takeover defences and suggests that other commonly employed defence tactics, including the lobbying of shareholders and regulatory appeals, have a weak and indecisive impact on bid outcome.

Alternatives are, of course, also available to the hostile bidder. A bear hug, for example, is an offer made directly to the directors of the target corporation to put pressure on them because it carries with it the implication that - if it is not favourably received - it will be followed by a tender offer. A tender offer is another alternative and could include an allcash tender offer or two-tiered tender offer; regulated by laws which set forth the rules within which an offer must be structured but also provide strategic opportunities for both parties. Finally, a proxy fight works through the corporate election proxy process where acquirers may bring about a change in control or seek more modest goals such as the enactment of shareholder provisions in a company's corporate charter (Gaughan, 2007). Takeover tactics are continually evolving and so too are anti-takeover tactics and defence approaches (Bebchuk \& Cohen, 2005; Bebchuk, Cohen, \& Ferrell, 2009; Gaughan, 2007; Schoenberg \& Thornton, 2006). More investigation is required to truly understand why friendly acquisitions can turn hostile and this paper therefore analysed such a case. Target boards have the discretion to share a bid with shareholders or to save the shareholders time and effort by refusing the bid out of hand. Acquirers in these instances have the option to turn hostile and make the offer directly to shareholders, bypassing the target board. The hurried nature of the introduction of a white knight bidder may contribute to the market perception that the strategic logic behind the bid was not sound (Sudarsanam \& Mahate, 2006). Figure 1, which in part summarises the literature review, illustrates the role players during a hostile takeover, as well as the governance mechanisms available and the international legislative and regulatory environments. 


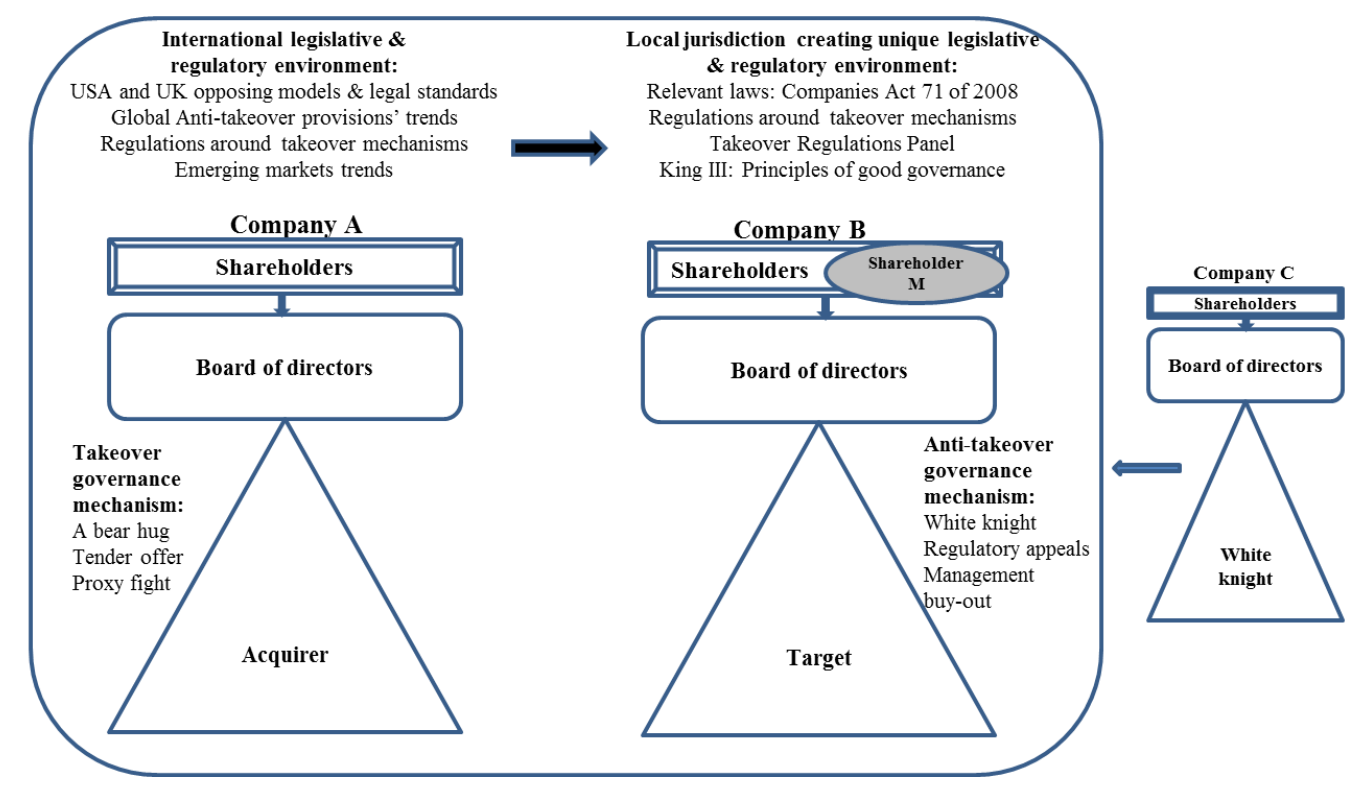

Figure 1: Diagram showing role players during hostile takeovers

\section{Research method}

The investigation of the main and three sub-research questions required a methodology that could describe and explore various sources of complex data as well as triangulate and verify these inputs. Creswell (2013) declares that qualitative research is by nature context sensitive. Barratt et al. (2011) defines a qualitative case study as empirical research that primarily uses contextually rich data from bounded real-world settings to investigate a focused phenomenon. As this research is an in-depth analysis of the existence, and/or extent, of the contextual impact of an acquisition that began as a normal business transaction, but quickly developed into a hostile takeover, a qualitative case study approach was chosen to best capture the underlying drivers that determined the success or failure of the hostile bid. Furthermore, the researchers purposefully set out to explore and develop an in-depth understanding of the multitude of dynamics involved in hostile takeovers and as such did not intend to generalise findings or establish causality nor external validity (Bryman, 2004; Eisenhardt, 1989(a); Peus, Braun, \& Frey, 2013; Yin, 2009).

The research design included four phases: data gathering; iterative processes to validate these data sets with archival data and SENS reports; additional interviews which were transcribed and coded; and cross-referencing these research outputs. One of the three researchers was peripherally involved in the hostile takeover under investigation and could be perceived as a researcher as insider (Babbie \& Mouton, 2009) with access to the interviewees and pre-, during- and post-bid documents. As a result, the research team took special care in testing and evaluating this particular researcher's observations and assumptions, and a rigorous peer review process was conducted during specific phases of the research process. For instance, prior to formulating the propositions, three preliminary informal discussions were conducted with key role players during which relevant literature, media releases and press reports were reviewed. Questions and follow-up questions posed to interviewees included, "which aspects of the context if any might have hindered or enabled the transaction?" and "how did managers respond to these aspects?" The preliminary interviews and inspection of relevant literature revealed two categories; the first was corporate governance mechanisms, and the second, legislative and regulatory environments. As a result, the main and three sub-research questions could be systematically investigated, given the run of events. During qualitative interviews, people were asked to describe particular events or episodes. They do this using episodic memory, according to Maxwell (2013). The researchers followed Maxwell's (2013) recommendations around identifying episodes to answer their first research sub-question.

The initial informal discussions were conducted within six months of the hostile takeover as the researchers did not want too much time to pass in case the role players struggled to remember key decision points during the hostile takeover process. During the first phase, the research questions determined specific areas of focus for the literature review. Desk review was conducted to enable understanding of the key influences in the drafting of the current legislation in South Africa, as well as a working knowledge of the legislated and regulatory requirements governing hostile acquisition processes. Relevant lectures on the new Companies Act were attended to enhance understanding. Consent was provided by the organisation and interviewees for the research and subsequent publication. The SENS announcements required by the JSE proved a valuable source of factual data from which a timeline was constructed. Newspaper reports, company websites, articles, television and radio interviews provided insights into management strategies, shareholder impressions and general market opinions on the progress of the transaction. Based on this flow of events, important decision points were identified and questions formulated for the interviews. The University of 
Pretoria's ethical clearance for the study was also a major milestone. The literature review revealed the two broad categories of contextual variables and these informed a conceptual framework or tool of hostile takeovers, and directed the interview questions, as Yin (2009) and Baxter and Jack (2008) advice. The interview schedule was peerreviewed by members of the research team.

Eisenhardt (1989) defined the key challenges to exploratory case study information gathering as the objective processing of the information and developing these insights into conclusions. The researchers therefore identified legislative requirements or hindrances that assisted or prevented actions being taken by either the acquirer or target team throughout the process, which supported the understanding of legislative and governance influencing factors. Yin (2003) describes six techniques for qualitative case study data analysis: pattern matching, linking data to propositions, explanation building, time-series analysis, logic models and cross-case synthesis (Baxter \& Jack, 2008). Findings were confirmed by corroborating interview data with secondary, external data, thereby ensuring that data represented in the case study findings was accurate.

During the next phase of the research, four in-depth interviews were conducted with key role players within the acquirer organisation as well as commercial law experts and financial advisors involved in the hostile takeover transaction. After the interviews were transcribed and coded, the results were compared with the other interviewees' perspectives. The flow of events of the hostile takeover was then formulated, based on these interviewees' perceptions. This flow was then corroborated with the initial formulation, based on archival data and press releases. Recorded radio and television interviews with leaders of the acquired organisation were analysed and used to validate perspectives from the acquirer organisation interviewees. Three follow-up interviews were conducted at this point to clarify perspectives of representatives of the acquirer organisation. This crossreferencing process or triangulate approach from various sources revealed a consistent sequence of events and provided a framework to draw up inferences and, ultimately, conclusions. Another thorough peer review process was conducted on these conclusions and finally the researchers could formulate answers to the research questions, illustrating the iterative validation and cross-referencing processes.

\section{Results and discussion}

The researchers focused their investigation on the main research question and three sub-research questions. The results will be discussed systematically, using these questions as a framework. Prior to answering these questions, the rich context of this particular case study is discussed.

\section{Context of hostile acquisition case study}

The target company was more than a century old and had underperformed its rivals both operationally and in the stock market in recent years, but had declared that its investments in factories, acquisitions and distribution partnerships with global companies had set it up for a turnaround. The company operated in South Africa, Sub-Saharan Africa and India. The target was listed on the JSE. Its published annual financial results disclosed significantly weakened financial ratios the year prior to the hostile acquisition. Although turnover was up, gross margins were down. Operating margin and net margin showed similar trends of decline. The acquisition of another business had put pressure on cash flows and resulted in significantly increased finance costs. The impact of increased gross margins, increased borrowing costs and expiry of tax allowances resulted in the declaration of a decline in headline earnings per share. These trading results, alongside decreasing efficiency ratios with working capital under pressure showing increased stock and debtor's days, investments in acquisitions and capital expenditure, resulted in an overall overdraft position.

Results of this nature attract the attention of the market place in general, raising questions about the reasons for the weakened performance of a leading company in an industry showing strong growth in both South African and international markets. They also attract the attention of potential investors and acquirers, both locally and internationally, who have access to capital that could drive a potentially underperforming company into a cash positive position. Investment opportunities are often characterised by the identification of a stable organisation with a recognised market position that has come under pressure, usually as a result of poor management, where a capital restructuring and a management change could result in sustainable growth and improved return on capital investment. These characteristics made the target ideal for any potential investor.

In reviewing the literature on hostile acquisitions, the researchers found support for the notion that the trigger for the hostile acquisition included the target company's underperformance, as described above. The researchers concluded that the internal governance mechanisms of the target board were ineffective in ensuring value-maximising behaviour by the incumbent management, triggering a response in the target's shareholders. See description of this trigger under Episode one in Table 1.

Interestingly, the acquirer organisation had not conducted a hostile acquisition previously. This organisation was at the time just under 30 years old, operated in a number of industries and had investments in companies outside the borders of South Africa, on five continents. The acquirer had conducted numerous negotiated acquisitions and had shown remarkable organic as well as acquisition growth, up until the time of this deal, giving it the opportunity to invest in other organisations and increase shareholding in its existing investments.

Results of research sub-question 1: What was the run of events in the proceedings of the preacquisition phase? 
The iterative research process of cross-referencing anecdotal accounts by interviewees, archival data and press interviews revealed eight distinct phases of the hostile takeover. The influence of legislative, regulatory and corporate governance on the run of events was established during each phase which will be reported in more detail under research question 2. The researchers' investigation identified three episodes during the pre-acquisition phase. Table 1 illustrates the three episodes: Episode one: Contextual influencers and offer; Episode two: Acquisition turning hostile; and Episode three: Post-turning point of hostile acquisition.

The paper further contributes to current literature on acquisitions by depicting the role players in this hostile takeover transaction. Table 1 offer these role players as for example: the acquiring organisation (acquirer) - this particular company was a conglomerate with various companies from various industries represented in a holding company. Activist investors are defined as investmentmanagement firms that have acquired beneficial ownership of a company and have intent to influence a management team (Cyriac, De Backer \& Sanders, 2014). The acquirer in this particular hostile takeover could be perceived as a shareholder activist. The acquired organisation is called the target, whereas the friendly acquirer from another continent is called the knight. The target and knight were companies from the same industry. One of the shareholders of the target owned $18.9 \%$ of the shares and is named Shareholder M in the table. Shareholder $M$ and the acquirer formed the consortium that achieved the target offer.

Table 1: Three episodes with eight distinct phases of a particular hostile takeover case, including milestones that influenced the proceedings to turn hostile and the role of legislation, regulation and governance

\begin{tabular}{|c|c|c|c|c|c|}
\hline $\begin{array}{l}\text { Episodes in hostile } \\
\text { takeover process }\end{array}$ & Phases & Events & Some activities & $\begin{array}{l}\Delta \text { Milestones influenced proceedings in turning hostile } \\
* \text { Researchers own inferences of how the hostile acquisition might } \\
\text { have been prevented; by following a friendly negotiated } \\
\text { acquisition process }\end{array}$ & $\begin{array}{l}\text { Role of New Act, regulations, } \\
\text { governance }\end{array}$ \\
\hline \multirow[t]{3}{*}{$\begin{array}{l}\text { Episode one: } \\
\text { Contextual } \\
\text { influencers and offer } \\
\text { (legislative, } \\
\text { regulatory } \\
\text { corporate } \\
\text { governance) }\end{array}$} & $\begin{array}{l}\text { Phase } \\
\text { one }\end{array}$ & $\begin{array}{l}\text { Target organisation } \\
\text { underperformed }\end{array}$ & $\begin{array}{l}\text { Target announced } \\
\text { financial results and } \\
\text { shareholders took action } \\
\text { to discipline } \\
\text { management Acquirer } \\
\text { solicited } 28 \% \text { support } \\
\text { from shareholders prior } \\
\text { to the offer }\end{array}$ & $\begin{array}{l}\Delta \text { Target's management had not adhered to shareholders' complaints } \\
\text { about recurrent financial decline } \\
\text { * If the target management would have been more open to their } \\
\text { shareholders' complaints and advice on a number of actions, such as } \\
\text { failed acquisitions, the acquisition and or hostile acquisition would } \\
\text { have been prevented }\end{array}$ & $\begin{array}{l}\text { In line with UK approach of protecting } \\
\text { shareholders' interests, new legislation } \\
\text { in South Africa was conducive to } \\
\text { shareholder activism }\end{array}$ \\
\hline & $\begin{array}{l}\text { Phase } \\
\text { two }\end{array}$ & $\begin{array}{l}\text { Acquirer made an } \\
\text { unsolicited offer }\end{array}$ & $\begin{array}{l}\text { Acquirer called their } \\
\text { offer a Scheme of } \\
\text { Arrangement }\end{array}$ & $\begin{array}{l}\text { * Through personal face-to-face interaction, prior to sending legal } \\
\text { documents, the target company might have been more open to the } \\
\text { offer }\end{array}$ & $\begin{array}{l}\text { In line with new Act, a SoA was offered } \\
\text { Court applications were no longer } \\
\text { necessary }\end{array}$ \\
\hline & $\begin{array}{l}\text { Phase } \\
\text { three }\end{array}$ & $\begin{array}{l}\text { Acquired (the target) } \\
\text { rejected offer on } \\
\text { technicalities }\end{array}$ & $\begin{array}{l}\text { The target called the } \\
\text { offer a non-binding } \\
\text { proposal and presented } \\
\text { concerns }\end{array}$ & $\begin{array}{l}\Delta \text { The target refused to share the offer with its shareholders } \\
* \text { If the target had shared the offer with its shareholders, the } \\
\text { shareholders might have anyway declined the offer and the acquirer } \\
\text { could have negotiated an improved offer etc. }\end{array}$ & $\begin{array}{l}\text { The target quoted from the new Act to } \\
\text { justify their refusal }\end{array}$ \\
\hline $\begin{array}{l}\text { Episode two: } \\
\text { Acquisition turning } \\
\text { hostile }\end{array}$ & $\begin{array}{l}\text { Phase } \\
\text { four }\end{array}$ & 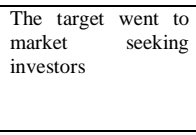 & $\begin{array}{l}\text { The target's response to } \\
\text { this offer was to invite } \\
\text { proposals from other } \\
\text { companies }\end{array}$ & $\begin{array}{l}\Delta \text { The target publicly refused and included the SoA letter in SENS } \\
* \text { Through private personal interaction, prior to public refusal, the } \\
\text { acquirer company might have been more open to a negotiated } \\
\text { acquisition }\end{array}$ & $\begin{array}{l}\text { JSE governance regulations prescribe } \\
\text { SENS announcements to ensure equal } \\
\text { access to information of all shareholders }\end{array}$ \\
\hline \multirow[t]{4}{*}{$\begin{array}{l}\text { Episode three: } \\
\text { Post-turning point of } \\
\text { hostile acquisition }\end{array}$} & $\begin{array}{l}\text { Phase } \\
\text { five }\end{array}$ & $\begin{array}{lr}\text { The } & \text { target } \\
\text { recommended } & \text { a } \\
\text { preferred bidder \& } \\
\text { offer }\end{array}$ & $\begin{array}{l}\text { The target explained the } \\
\text { benefits of the knight as } \\
\text { being a multinational in } \\
\text { the same industry with } \\
\text { presence in emerging } \\
\text { markets }\end{array}$ & $\begin{array}{l}\Delta \text { The target frustrated the bid and did not inform shareholders of the } \\
\text { acquirer's offer, instead preferred the knight's offer } \\
\text { * If the target management shared the two options openly with their } \\
\text { shareholders, instead of frustrating the bid by only offering the } \\
\text { knight's offer, the takeover might not have turned antagonistic } \\
\triangle \text { SENS intended to equip shareholders with info, } \\
\text { * but might have been used as an influencing tool to sell the benefits } \\
\text { of the board's preferred choice } \\
\text { * JSE regulations of public communication through SENS, might } \\
\text { have been overused in this particular case, whereas more informal } \\
\text { ways could have prevented antagonistic responses }\end{array}$ & $\begin{array}{l}\text { Section 126(1)(a)-(g) of the Companies } \\
\text { Act (2008) specified prohibited actions: } \\
\text { There is the positive fiduciary duty to } \\
\text { inform shareholders of the offer and the } \\
\text { negative duty not to frustrate the bid - } \\
\text { in the interest of the company } \\
\text { The detailed SENS information met the } \\
\text { requirements of the JSE, and went } \\
\text { beyond. }\end{array}$ \\
\hline & $\begin{array}{l}\text { Phase } \\
\text { six }\end{array}$ & $\begin{array}{l}\text { Acquirer consortium } \\
\text { made direct offer to } \\
\text { shareholders }\end{array}$ & $\begin{array}{l}\text { The target only } \\
\text { presented the knight's } \\
\text { offer and acquirer went } \\
\text { directly to the target's } \\
\text { shareholders }\end{array}$ & $\begin{array}{l}\Delta \text { The target again refused to share the offer with its shareholders } \\
* \text { If the target management had shared the two options openly with } \\
\text { their shareholders, instead of frustrating the bid by only offering the } \\
\text { knight's offer, the takeover might not have turned antagonistic }\end{array}$ & $\begin{array}{l}\text { New Companies Act, section S127(3) } \\
\text { declared a } 12 \text { month restriction period } \\
\text { within which the initial SoA could be } \\
\text { resubmitted. It led acquirer to present } \\
\text { the offer directly to shareholders in a } \\
\text { crucial turning point in run of events }\end{array}$ \\
\hline & $\begin{array}{l}\text { Phase } \\
\text { seven }\end{array}$ & $\begin{array}{l}\text { The knight (friendly } \\
\begin{array}{l}\text { acquirer) revised } \\
\text { offer }\end{array}\end{array}$ & $\begin{array}{l}\text { The knight revised offer } \\
\text { to gain approval from } \\
\text { the target's majority } \\
\text { shareholder } \\
\text { (Shareholder M) }\end{array}$ & $\mathrm{n} / \mathrm{a}$ & $\begin{array}{l}\text { The knight's requirement of financial } \\
\text { assistance had required approval from } \\
75 \% \text { majority shareholders and this } \\
\text { section S44 was not adhered to, offering } \\
\text { the acquirer the opportunity to get a } \\
\text { court order }\end{array}$ \\
\hline & $\begin{array}{l}\text { Phase } \\
\text { eight }\end{array}$ & $\begin{array}{l}\text { Acquirer set deadline } \\
\text { and achieved target } \\
\text { offer for } 34,5 \% \text { of the } \\
\text { target }\end{array}$ & $\begin{array}{l}\text { Acquirer blamed the } \\
\text { target for delaying } \\
\text { transaction with the } \\
\text { knight and set deadline } \\
\text { after the knight's offer } \\
\text { expiry date }\end{array}$ & $\begin{array}{l}\Delta \text { The target company had not accepted the first offer of the acquirer } \\
\text { and therefore the acquirer could make another offer within a year } \\
\text { * Had the first offer been accepted and dealt with than any other } \\
\text { acquisition offer, the deal would have gone through as a negotiated } \\
\text { friendly acquisition or not have taken place }\end{array}$ & $\begin{array}{l}\text { A company is not allowed to make } \\
\text { another offer within twelve months of } \\
\text { the first offer. Yet the first offer was } \\
\text { never accepted, and therefore the } \\
\text { acquirer could submit another offer. The } \\
\text { acquirer's consortium achieved less } \\
\text { than } 35 \% \text { of the shares, to prevent a } \\
\text { control stake }\end{array}$ \\
\hline
\end{tabular}

Note: $\Delta$ Symbol indicating a milestone that influenced the proceedings that followed to turn hostile.

Should the target company's management had chosen a different action, these milestones would have changed the proceedings to possibly a negotiated acquisition.

* Researchers' own inferences of how a friendly negotiated offer might have been the result than a hostile acquisition and thus how this turn of events might have been prevented. 
Episode one illustrates the findings of this particular case study: The researchers discovered that in this particular hostile acquisition, the run of events could have been prevented if the original target board's internal disciplinary processes had been more effective. If it is perceived that the board is not delivering according to required standards, shareholders have the right to express dissatisfaction with the board, to the extent that they can effect a change in the board membership, should it be required. Academic scholars, for example Fisman, Khurana, Rhodes-Kropf \& Yim (2014) declare that shareholders should challenge the board and the management about their investments to ensure they are realising the true benefits of strategic decisions to increase returns. Research conducted by Shivdasani (1993) is relevant in estimating equations to predict the probability of a hostile takeover as a function of governance characteristics. Should the management team of a target entity realise its underperformance, it is seldom prepared to take responsibility for the results, choosing instead a process of negotiation, delaying tactics to buy time or identifying an alternate acquirer where an arrangement can be made to secure their positions.

Episodes two and three in Table 1 illustrate these manoeuvring tactics of the target company in the particular case study. While this case study focused on three episodes within the pre- acquisition phase, as depicted in Table 1, there are of course a number of other episodes that regularly follows the pre-acquisition phase. Cummings and Worley (2015), for example, identify the pre-acquisition phase, the actual deal and post-acquisition integration phases. Further studies might build on this investigation by considering the impact of these pre-acquisition episodes on the postacquisition integration process of the acquirer and target company of this case study.

The second research question revolved around the contextual influencers during these episodes.

Results of research question 2: How did new regulations, and governance policies alongside the new legislation, play a role in the acquisition turning hostile?

The significant role played by legislative requirements throughout this transaction is illustrated by the findings of the study. Given that the new Companies Act had only been in place for approximately four years, and there had not been many instances of hostile bids in South Africa, there was not an extensive library of case law or application that had been tested regarding hostile bid processes. The hostile bid process in this case study stretched the interpretation of available guidance, which in most cases had been drafted with friendly acquisition processes in mind. The findings of this research question will be discussed systematically using the threeepisode framework of Table 1 .

\section{Episode one: Contextual influencers and offer}

The requirements for making a Scheme of Agreement (SoA) offer is set out in the Companies Act, and enforced through the oversight of the Takeover Regulation Panel (TRP) of South Africa. These sections of the Act are defined - above. The interpretation of the requirements for a SoA is still being challenged, however, as evidenced in the target's argument when refusing to acknowledge the initial unsolicited offer from the acquirer, arguing that the TRP requirements for a SoA had not been met. Yet, in refusing to recognise this initial letter as a valid offer document, the target created an opportunity for the acquirer to make another offer directly to the target's shareholders, within the 12-month restriction period per the Companies Act, S127(3). Therefore the target, by applying the letter of the law initially and arguing the validity of the offer from the acquirer, opened the door for the acquirer to submit a revised offer later on at a crucial turning point in the sequence of events.

The researchers suspect that if it were not for the refusal of the management team to share the SoA offer with its shareholders, the proceedings that ensued would have followed a different direction.

Under the new Companies Act, an automatic court application is no longer required. This resembles the UK approach of self-regulation, as opposed to a highly litigated process. With very little litigation, combined with the limited role of lawyers, the takeover process in the UK is faster and cheaper than in the USA (Armour \& Skeel, 2007). The UK system protects the shareholders of the company (Bates, Becher, \& Lemmon, 2008). With the significant presence of institutional shareholders, management has little sway when acquisition advancements are made. Burkart et al. (2014) found that takeover outcomes are more efficient in countries with stronger legal investor protection.

Dignam (2007), however, lists challenges with the adoption of the UK principles in other countries, such as the size of the stock exchange in relation to the size of the local economy. Nearly two thirds of large UK companies are listed on the London Stock Exchange (LSE) whereas the shareholder base in emerging markets is a much smaller pool of investors than would be the case in the UK or the USA. These restrictions closely resemble the economic landscape encountered in South Africa. We argue in favour of Dignam's (2007) findings that there are difficulties with transplanting the UK model into Australia with its different labour law legislation, and his argument against a one-size-fits-all model. South African labour law legislation is undergoing changes and these unique circumstances would have to be considered, as staff and unions are important organisational stakeholders. The King III code declares that the needs of a number of stakeholders must be considered, in addition to those of shareholders (Institute of Directors in Southern Africa, 2009a). The researchers focused their investigation on the proceedings of the pre-acquisition phase, during which the shareholders played an important role. As a result, the other stakeholders do not receive much attention in this paper. It 
will be important for future research to consider the target organisation's management and staff as stakeholders as well, particularly in post-acquisition phases which regularly include retrenchments.

During episode one, the acquirer presented an offer with restrictions that prevented management from engaging in entrenchment or anti-takeover tactics, such as restrictions on dividend payments. The acquirer solicited $28 \%$ support from key shareholders prior to submitting the offer letter. The researchers' investigation thus revealed that the acquirer's CEO indeed met with executive management and the chairman of the board of the target.

\section{Episode two: Acquisition turning hostile}

The target's management was taken by surprise, realised they were under threat and blamed technicalities for refusing to present the offer to shareholders. The target rejected the offer as a void offer, stating that it was little more than a letter of intent and that this offer should have met all requirements of the JSE, TRP and Competition Commission. Usually a board would present the offer to shareholders and $75 \%$ of them would have to approve it. The acquirer perceived the refusal as insubstantial and wanted the scheme to at least be presented to the shareholders. Douglas and Oppenheim (2013) highlight section 115 of the Companies Act 2008, which specifies that a company may not enter into or implement a fundamental transaction unless that transaction has been approved by a shareholders' special resolution.

The manner in which the target responded was a choice made by the board at that time. The study reveals that if the board had responded directly to set up face to face meetings with the acquirer to unpack the conditions and terms of the offer, it could have been discussed and possibly gained board support or no support for the offer presented to shareholders. In this scenario, the outcome could have included a negotiated or friendly acquisition.

Instead, the board chose to publish the offer letter and question the validity of the offer on technical grounds. The researchers found that, perhaps unwittingly, the target created a negative environment which elicited a hostile response from the acquirer. A threshold of a hostile acquisition was therefore formed. The acquirer was frustrated that the target board was making a decision on behalf of the shareholders and was probably not properly fulfilling its fiduciary duties. The board could have presented all viable offers to the shareholders and made recommendations to them regarding which offer it thought most suited for the creation of long-term shareholder wealth.

The researchers found that regulations and governance policies also influenced the direction of the acquisition. For example, the fact that the JSE requires SENS announcements from all listed entities also played a significant role throughout this transaction. The acquirer had submitted its initial unsolicited offer to the board of the target, requesting it be presented to the shareholders. The target chose to respond by refusing to recommend the offer, and published the full offer letter in a SENS announcement shortly thereafter. This public refusal of the acquirer's offer was partly responsible for triggering the hostile response from the acquirer.

These findings suggest that bids turn hostile when the target company's management and board use anti-takeover governance structures to protect themselves by exploiting governance structures afforded by anti-takeover provisions.

\section{Episode three: Post-turning point of hostile acquisition}

The study reveals that JSE regulations also played a role in the proceedings during episode three: The target expressed its concerns in the SENS announcements, for example that the acquirer had not had exposure to its particular industry. This response frustrated the acquirer. In response to the acquirer's proposal, the target used its independent board, as per King III principles and the new Companies Act, to request proposals from the market for a potential acquisition. In a sense the target's management team went in search of a friendly acquirer or white knight. The subsequent detailed SENS announcements of the knight's offer went beyond the requirements of the JSE. The information shared was intended to equip shareholders with sufficient information to be able to make a sound decision, but the researchers are of the opinion that it might have also been used as an influencing tool to sell the benefits of the board's preferred choice.

A formal proposal process was established in line with JSE rules and TRP requirements. A non-disclosure agreement was formulated for all respondents to sign. The acquirer resubmitted its initial offer but the target refused to acknowledge or recognise the previous offer, stating that the conditions were not achievable. The target invited the acquirer to submit a new offer with less conditionality. The acquirer declined on the basis that this would be overly onerous and designed to place the target's management in a position of control. The non-disclosure agreement was of particular concern. Again, the target board had still not informed its shareholders of the acquirer's initial offer. The target also exercised delaying tactics, taking more than seven months from invitation to presenting the knight's offer to shareholders. Admittedly, the target's rejection of the initial offer forced the acquirer to increase their offer, which would have increased shareholder wealth. The knight also increased its offer. The SENS reports, prescribed by the JSE, maintained a positive outlook on the knight's offer to the end, without explaining the benefits and disadvantages of both offers. The fact that the knight's offer lacked a timeframe or examples of how synergies between the target and knight would be realised, did not prevent the target from proclaiming the advantages of the offer.

At this point, $45 \%$ of the shareholders signed irrevocable undertakings in favour of the knight's offer but the main shareholder (Shareholder M) did not sign the offer, based on price. At this stage, the target refused to share information 
with the acquirer, as a bona fide offeror, using the new Companies Act technicalities as a defence. The target's board recommended the knight's SoA to shareholders as the only offer it believed to be worth their time and effort to consider. The knight's offer explicitly stated that the target's CEO would be retained, but that additional board and executive members from the knight would to be assigned to the target's executive committee and board. The knight's offer detailed synergy benefits without disclosing the time period or margins.

The acquirer warned the target that it was a bona fide potential offeror and, per the Companies Act, was entitled to information about the knight's offer. The target argued per Companies Act S127(3) that the acquirer was prohibited from making another offer within 12 months and recommended the acquirer approach the TRP to submit another offer. The acquirer responded with a court application, which was withdrawn as the target's board conceded to reveal the details of the knights' offer. The knight's SoA detailed how the $100 \%$ acquisition of the target would be made up. The knight would have to raise funds to cover the cash portion of the offer, through an additional share offer through its country of origin's listing. Depending on cash raised, the offer would be a split of cash and shares. The knight fulfilled the requirements of a friendly acquirer role. It was supportive of the current management team and presented an offer to shareholders with significant synergy benefits that had not been identified prior to the unwanted initial hostile bid from the predatory acquirer. Interestingly, frustrating actions by managers to eliminate or prevent offers are regarded with some concern as they are most times perceived to be harmful to maximising shareholder wealth (Jensen, 1988). Acquired firms' shareholders could earn more, on average, in hostile than in friendly takeovers and potentially could support the hostile acquirer.

The researchers found that in this particular hostile acquisition, the introduction of the knight's bid corresponded with Schoenberg and Thornton's (2006) statistical analysis that white knights would have been the most effective takeover defence, apart from management buy-outs (which were not applicable in this case). Yet, additional financing arrangements were included in the knight's offer, with a guarantee issued by the target. This constituted financial assistance and required approval from $75 \%$ of the majority shareholders as per the Companies Act S44. The acquirer lodged a court action as shareholder of the target, stated that the target board had not complied with applying for permission to render financial assistance, per the Companies Act. This matter was not presented as urgent and the target responded that it would present arguments in three months' time. The acquirer presented a cash only offer, but this was lower than the majority shareholder expected. The transaction between the target and knight was prolonged and no reasons for the delay were offered.

The acquirer used the Companies Act S44 financial assistance requirements to lodge a court application against the knight's offer and the intended special resolutions shareholders meeting, stating that shareholders had to vote on the financial assistance resolution prior to voting on the knight's offer. The knight announced that the share issue at its local country stock exchange resulted in a more favourable result than anticipated and was able to increase its offer. The target and knight both denied all allegations in the acquirer's court application, stating they had complied with all legal requirements as advised by their South African legal team. Two significant shareholders, one of them being Shareholder M, increased their shareholding in the target. Shareholder irrevocable undertakings signed in favour of the knight's deal expired and these shareholders were no longer bound to support this deal.

The knight's offer was still valid but the target announced that this offer was terminated as well as the TRP exemption of R50 million contractual obligations. Two shareholders, both previous supporters of the knight's offer, had offered their shares to the hostile acquirer, once their irrevocable undertakings had expired. Clearly, shareholders' confidence in the knight's offer had begun to wane and the soon-to-expire acquirer cash offer, as well as its court application, had had the intended effect. Per JSE requirements, the target had alerted shareholders of an anticipated decline of more than $20 \%$ on the prior year's results at half year, due to cost inflation, the depreciating rand and other factors.

The acquirer and Shareholder M combined held more than $50 \%$ of the target's shares and the knight recognised that there was little likelihood of a successful outcome for its offer. The only remedy available was consensual agreement between the knight and target to terminate the offer and present this to the TRP for approval and release from the break free clause. The target's board attempted to stop the acquirer's offer using S127(3) of the Companies Act, that states that once an offer is made, and has subsequently lapsed or been withdrawn, the offeror may not make another offer on the target for a period of twelve months (Parliament of the Republic of South Africa, 2011). The target argued that the acquirer should be prohibited from making another offer within twelve months of the first offer. However, as the target's board had rejected the validity of the first acquirer offer, and had never presented the offer to its shareholders for consideration, this argument was overruled. The target management team was criticised for taking its eye off its business for ten months, focussing instead on avoiding the acquirer's advances. Trading results were down on an already poor performance. The acquirer created a consortium and offered to acquire up to $34,5 \%$ of the target, in cash only directly to shareholders, avoiding the regulated control limit in South Africa of 35\%, which in terms of the Companies Act did not trigger a S123 Mandatory Offer of the offered price to all shareholders.

Based on these results, we argue that the South African regulatory framework indeed effectively prohibited antitakeover provisions, influencing the outcome of the hostile acquisition. 
Results of research question 3: Which acquisition theories on motives and relatedness were applicable in the pre-acquisition phase of this particular case study?

The researchers established that the Theory of Agency played itself out in the case under investigation: Wright et al. (2002) warn against management of target organisations looking after their own welfare, to the detriment of their shareholders. In this case, the management and board of the target organisation executed delay tactics to frustrate a bid and refused to share the SoA with their shareholders. The duty of directors is not to secure their own future, but instead to make the tough decisions required to maximise value in the company (Clarke \& Brennan, 1990; Merrett \& Houghton, 1999; Sinha, 2004; Weisbach, 1993).

This article argues in favour of the perspective of BeckerBlease (2011), Gaughan (2007) and others that managers exploit the corporate governance mechanisms offered by antitakeover provisions. Shareholders were notably excluded from the acquisition decisions as they were not informed of the acquirer's offer. South Africa's regulatory framework allows executives to exercise significant autonomy when making decisions that directly impact the shareholders' interest in maximising wealth (Clarke \& Brennan, 1990; Myles \& Young, 2014; Pearce \& Robinson, 2004; Ryngaert $\&$ Scholten, 2010). Nonetheless, the board of directors of an organisation has a duty to the shareholders that appointed each member of that board to act in the best interests of the company and to improve its economic value while still achieving the overarching corporate governance principles of fairness, accountability, responsibility and transparency.

Generally, hostile takeovers include a major restructuring of the management of the target company, relating to the Hubris Theory of Seth et al. (2002), in which the acquirer declares that the target company would be more successful under its management. In this case, the acquiring company's leadership was frustrated by the public refusal of its bid, the fact that its initial letter was negated as an invalid offer and the ongoing reasons - based on the new legislation - given as to why the board did not offer the bid to its shareholders. Pearce and Robinson, (2004) predict that the incumbent target management team will argue that the rationale for fending off unsolicited offers includes the desire to retain autonomy or management control, the preference for an alternative partner, the belief in a historical business objective that would be compromised by new management, or the desire to negotiate a more favourable financial takeover. In this case, the SENS announcements consisted of detailed reasons for the attractiveness of the knight's offer.

The case study also revealed the relevance of the Discipline Theory of Martin and McConnel (1991). De Pamphilis (2012) declares that globally, a free market economy facilitates the efficient allocation of resources and also provides transparent publicly-available financial performance information to evaluate managers' performance as well as a mechanism for disciplining them, such as hostile takeovers. Whether this particular hostile acquisition will deliver value for the shareholders of the acquirer and/or the target remains to be seen. It has been argued that hostile takeovers are beneficial turnaround strategies (Weisbach, 1993), but the viability of this particular hostile takeover as a turnaround strategy for the target will only become apparent after around three to five years.

The same applies to the Process School of thought of Larsson and Finkelstein (1999), which holds that acquisitions of companies in unrelated industries is negatively correlated with performance, as it will likewise take a couple of years before it can be established whether the new management and board will turn the target organisation around.

\section{Limitations and recommendations for future studies}

Limitations of this research include the fact that it studied a single hostile takeover transaction that took place between two JSE-listed entities. As the study focused on a single hostile acquisition, it lacks the ability to be widely applied or generalised for the building of academic theory (Barratt et al., 2011; Eisenhardt, 1989(b); Ravenswood, 2011). Nonetheless, the study reveals that many factors contributed to the outcome of the transaction, not least of which was the nature, experience and reputation of the two leaders of these companies. It would be impossible to completely separate the individuals at the helm, supported by their teams of advisors, from the flow of events tracked in this case study. The focus of the case study was corporate governance mechanisms and regulatory impacts, but the application and use of these mechanisms by the leaders, supported by their advisory teams, were also significant role players.

Future research should not limit the population to successful takeover bids, but should include attempted hostile takeovers that were blocked through the use of the same legislation and regulations studied in this case study. The outcome of the takeover attempt does not demonstrate the validity or completeness of the legislative and regulatory environment; rather, it shows the ability of that environment to create the mechanisms and tools that company owners can use to pursue their strategies. Longitudinal research is recommended into whether the target company's profit returns increase after the hostile acquisition. Extension of this work might give us a more complete understanding of the consequences of takeover resistance. It will also be important for future research to focus on the link between the proceedings during the pre-acquisition phase and the post-acquisition consequences of this particular case.

\section{Conclusion}

The study found that post-2008 legislation did indeed have far-reaching influence on all three episodes in the preacquisition phase, as illustrated in Table 1. Legislation forced the hand of both the acquirer and target entities during this transaction, as follows: 
Regulatory disclosure requirements, legislated guidance from the JSE, King III and the new Companies Act actually resulted in the target board being unable to block the advances of a strong consortium bid. The international friendly buyer was blocked, and a controlling stake acquired by significant shareholders, resulting in a very different future for both the target company's management team and strategy. The fact that the shareholders of the target company were free to accept a takeover bid, without board interference, is testament to a well-functioning regulatory and corporate governance environment (Schoenberg \& Thornton, 2006).

The target company was unable to impede, frustrate or defeat an offer, or prevent shareholders from making fair and informed decisions (Douglas \& Oppenheim, 2012, 2013), which demonstrates that South Africa's corporate environment focuses on shareholder democracy, or the rights of shareholder communities. Legislation ensured that neither entrenchment of the target management nor anti-takeover provisions was permitted in South Africa's public arena.

In this particular case the board was bypassed and an acquisition offer was indeed made directly to the shareholders. Obviously a key turning point in the flow of events came about when, following the detailed announcement of the final offer from the knight, the acquirer responded by challenging the legality of the offer document by claiming it contravened S44 of the Companies Act. On this basis, the acquirer lodged a court application against the knight's offer to shareholders, and challenged the general meeting that had been scheduled to vote on this offer. The intent of the post-2008 legislation is to create an environment that does not require court application for every transaction, as was previously the case. The new legislation is intended to allow market forces to play out in a free market economy, while ensuring there are remedies available to protect shareholder wealth. It is debatable whether this intention of the legislation is being achieved, for example in this case, the legislation provided protection for a management team despite its weak performance track record.

The successful hostile bid for the target by the acquirer was a function of the combined mechanisms, tools and decisions taken by the acquirer team, the acquired board and the shareholders looking to maximise their return on investment. The new legislative environment offered some opportunity to initiate a hostile bid, but also blocked these efforts when the target's management interpreted the law differently. Legal remedies available to the acquirer, once blocked by the target's management team, were scarce and it appeared that the hostile acquisition attempt by the acquirer would fail. It was not until the knight's offer was published that the acquirer could renew its attempts to acquire the target company by challenging the legality of the knight's offer. The outcome of the transaction was the result of a mixture of legal interpretations, the timing of proposals and responses, as well as what were probably deliberate delaying tactics. Corporate governance mechanisms, as well as the legal and regulatory environment, determined the boundaries within which the players in this case could act. How the response was delivered was also a function of the legislative and regulatory boundaries.

Although there are some limitations to this case study, inferences drawn from the data can inform managers and advisors in hostile takeover situations. For instance, this research highlights the impact of legislation and regulation in effecting a public company transaction. South Africa's corporate environment is considered small by international standards. It is a tight-knit environment in which all actions are noted and scrutinised. Although the new Companies Act has been in effect for more than four years, it has not yet been tested in a variety of circumstances and there is therefore not a long history of case law and rulings to guide the actions taken by corporate teams and investors. Shareholders and boards should therefore be aware that the current legislative environment is still gaining traction. The emphasis of the legislation is to protect shareholders, in particular minority shareholders, and a hostile bid is more likely to be unsuccessful than successful. However, as time progresses and more potential hostile acquisitions are challenged, courts will be required to give rulings and create precedents for the market place.

This article provides perspectives on the manoeuvring by both the acquirer and acquired company, and illustrates that hostile acquisitions are extensively influenced by legislative, regulatory and corporate governance factors.

\section{References}

Aka, P.C. 2007. 'Corporate governance in South Africa: Analyzing the dynamics of corporate governance Reforms in the 'Rainbow Nation", North Carolina Journal of International Law and Commerce, 220-296.

Armour, J. \& Skeel, D.A.J. 2007. 'The divergence of U.S. and UK takeover regulation', Regulation, 30(3): 50-59.

Babbie, E. \& Mouton, J. 2009. The practice of social research. Cape Town: Oxford.

Barratt, M., Choi, T.Y. \& Li, M. 2011. 'Qualitative case studies in operations management: Trends, research outcomes, and future research implications', Journal of Operations Management, 29(4): 329-342.

Bates, T.W., Becher, D.A. \& Lemmon, M.L. 2008. 'Board classification and managerial entrenchment: Evidence from the market for corporate control', Journal of Financial Economics, 87(3): 656-677.

Baxter, P. \& Jack, S. 2008. 'Qualitative case study methodology: Study design and implementation for novice researchers', The Qualitative Report, 13(4): 544-559.

Bebchuk, L.A. \& Cohen, A. 2005. 'The costs of entrenched boards', Journal of Financial Economics, 78(2): 409-433.

Bebchuk, L., Cohen, A. \& Ferrell, A. 2009. 'What matters in corporate governance?', Review of Financial Studies, 22(2): 783827. 
Becker-Blease, J.R. 2011. 'Governance and innovation', Journal of Corporate Finance, 17(4): 947-958.

Bernstein, D. 2014. 'Corporate governance quarterly: should shareholders have a voice?', International Financial Law Review, August:1-5.

Bertrand, M. \& Mullainathan, S. 2003. 'Enjoying the quiet life? Corporate governance and managerial preferences', Journal of Political Economy, 111(5): 1043-1075.

Blackshaw, S. 2014. '2014 Mergers and Acquisitions Report: UK', International Financial Law Review, March, 1-7.

Birkinshaw, J., Bresman, H. \& Hákanson, L. 2000. 'Managing the post-acquisition integration process: How the human integration and task integration processes interact to foster value creation', Journal of Management Studies, 37: 395-425.

Bryman, A. 2004. 'Qualitative research on leadership: A critical but appreciative review', The Leadership Quarterly, 15(6): 729769.

Burkart, M., Gromb, D., Mueller, H.M. \& Panunzi, F. 2014. 'Legal investor protection and takeovers', Journal of Finance, 69(3): $1129-1165$.

Cassim, F.H.I., Cassim, M.F., Cassim, R, Jooste, R., Shev, J. \& Yeats, J.L. 2012. Contemporary Company Law. Claremont: Juta.

Chakraborty, A., Rzakhanov, Z. \& Sheikh, S. 2014. 'Antitakeover provisions, managerial entrenchment and firm innovation', Journal of Economics \& Business, 72: 30-43.

Clarke, C.J. \& Brennan, K. 1990. 'Defensive strategies against takeovers: Creating shareholder value', Long Range Planning, 23(1): 95-101.

Creswell, J.W. 2013. Qualitative inquiry and research design: Choosing among five traditions. $3^{\text {rd }}$ Edition. Los Angeles: Sage Publications.

Cummings, T.G. \& Worley, C.G. 2015. Organizational Development and Change. $10^{\text {th }}$ Edition. Stamford, CT: Cengage Learning.

Cyriac, J., De Backer, R. \&Sanders, J. 2014. 'Preparing for bigger, bolder shareholder activists', McKinsey Quarterly, (2): 113-118.

Davis D. \& Le Roux M. 2012. 'Changing the role of the corporation: A journey away from adversarialism.' Acta Juridica, 306-325.

Delport P. 2011. The New Companies Act Manual. Durban: LexisNexis.

Delport P. et al. 2011. Henochsberg on the Companies Act 71 of 2008. Durban: LexisNexis.

Demidova, E. 2007. 'Hostile takeovers and defenses against them in Russia', Problems of Economic Transition, 50(5): 44-60.

DePamphilis, D.M. 2012. The corporate takeover market: Common takeover tactics. In Antitakeover defenses, and corporate governance. San Diego: Academic Press.
Dignam, A. 2007. 'Transplanting UK takeover culture: The EU takeovers directive and the Australian experience', International Journal of Disclosure \& Governance, 4(3): 148-166.

Douglas, C. \& Oppenheim, J. 2012. 'South Africa: Heating up', International Financial Law Review, April:1-7.

Douglas, C. \& Oppenheim, J. 2013. 'What's impacting South African takeovers', International Financial Law Review, March:17.

Du Plessis, R. 2009. 'South Africa: New companies bill', International Financial Law Review, June:1-6.

Eisenhardt, K.M. 1989(a). 'Agency theory: An assessment and review', Academy of Management Review, 14(1): 57-74.

Eisenhardt, K.M. 1989(b). 'Building theories from case study research', Academy of Management Review, 14(4): 532-550.

Fisman, R.J., Khurana, R., Rhodes-Kropf, M. \& Yim, S. 2014 'Governance and CEO turnover: Do something or do the right thing?', Management Science, 60(2): 319-337.

Gaughan, P.A. 2007. Mergers, Acquisitions, and Corporate Restructurings. $4^{\text {th }}$ Edition. New York: John Wiley.

Galpin, I. \& Herndon, M. (2007). The complete guide to mergers and acquisitions: Process tools to support $M \& A$ integration at every level. San Francisco: Jossey-Bass.

Hitt, M.A, Ireland, R.D. \& Hoskisson, R.E. (2007). Strategic Management: Competitiveness and Globalisation Concepts. SouthWestern: Thomson.

Hopkins, S. \& Corte, L. 2014. 'Why UK activism is here to stay', International Financial Law Review, August:1-7.

Institute of Directors in Southern Africa. 2009a. King III Practice Note: Introduction \& Background Fundamental and Affected Transactions. Johannesburg, South Africa.

Institute of Directors in Southern Africa. 2009b. King Code of Governance Principles for South Africa 2009. Johannesburg: IodSA.

Jensen, M.C. 1988. 'Takeovers: Their causes and consequences', Journal of Economic Perspectives, 2(1): 21-48.

KPMG. 2012. Toolkit for the Company Director. $3^{\text {rd }}$ Edition. Johannesburg: KPMG.

Larsson, R. \& Finkelstein, S. (1999). Integrating strategic, organisational and human resource perspectives on mergers and acquisitions: A case survey of synergy realisation. Organisation Science, 10: 1-26.

Levitt, D. \& Bee, K. 2009. 'Surviving the hostile bid: corporate', Inside Mining, 2(1): 40-47.

Marks, M. \& Mirvis, P. 2010. Joining Forces: Making one plus one equal three in mergers, acquisitions, and alliances. Second edition. San Francisco: Jossey-Bass.

Martin, K.J. \& McConnell, J.J. (1991). Corporate Performance, Corporate Takeovers and Management Turnover. Journal of Finance, 56: 671 -687. 
Matsaneng, M.E. 2010. 'The Role and Consequences of Pure Corporate Control and Corporate Social Responsibility in the Republic South Africa and the United States of America'. University of Free State.

Maxwell, J.A. 2013. Qualitative Research Design: an Interactive Approach. 3rd Edition. London: Sage.

Merrett, D.T. \& Houghton, K.A. 1999. 'Takeovers and corporate governance: Whose interests do directors serve?’ Abacus, 35(2): 223-240.

Mohamed, S. 2010. The effect of a mainstream approach to economic and corporate governance on development in South Africa. In Edigheji, O. (Ed.), Constructing a democratic developmental state in South Africa: Potentials and challenges. Cape Town: HSRC Press.

Myles, D. \& Young, T. 2014. 'Tips: when M\&A gets hostile', International Financial Law Review, June:1-3.

Nickig, J., 2011. 'Hat's off, gentlemen (and ladies), to one of your greatest generals: company international law', Without Prejudice, 11(6): 22-24.

Olaerts, M. \& Schwarz, C.A. 2012. Shareholder democracy: An analysis of shareholder involvement in corporate policies. Amsterdam: Eleven International Publishing.

Parliament of the Republic of South Africa. COMPANIES ACT 71 OF 2008. 2011. South Africa: Department of Justice and Constitutional Development. [online]

URL:http://www.justice.gov.za/legislation/acts/2008-

071amended.pdf

Pearce, J.A.O. \& Robinson, R.B. 2004. 'Hostile takeover defenses that maximize shareholder wealth', Business Horizons, 47(5):1524.

Peus, C., Braun, S., \& Frey, D. 2013. 'Situation-based measurement of the full range of leadership model — Development and validation of a situational judgment test', The Leadership Quarterly, 24(5): 777-795.

Ravenswood, K. 2011. 'Eisenhardt's impact on theory in case study research', Journal of Business Research, 64(7): 680-686.

Ryngaert, M. \& Scholten, R. 2010. 'Have changing takeover defense rules and strategies entrenched management and damaged shareholders? The case of defeated takeover bids', Journal of Corporate Finance, 16(1): 16-37.

Seth, A., Song, K.P. \& Pettit, R. 2000. 'Synergy, managerialism or hubris? An empirical examination of motives for foreign acquisitions of U.S. firms', Journal of International Business Studies, 31: 387-405.

Schoenberg, R. \& Thornton, D. 2006. 'The impact of bid defences in hostile acquisitions', European Management Journal, 24(2-3): $142-150$.

Sherman, A. \& Hart, M. (2006). Mergers and Acquisitions from A to Z. 2nd edition. New York: Amacon.

Shivdasani, A. 1993. 'Board composition, ownership structure and hostile takeovers', Journal of Accounting and Economics, 1(16): 167-198.
Sinha, R. 2004. 'The role of hostile takeovers in corporate governance', Applied Financial Economics, 14(18): 1291-1305.

SRP v MGX Holdings Ltd (unreported case no 16026/03 of the High Court Witwatersrand Local Division).

Stein, C., \& Everingham, G.K. 2011. The New Companies Act Unlocked. Johannesburg: Siber Ink.

Sudarsanam, S. \& Mahate, A.A. 2006. 'Are friendly acquisitions too bad for shareholders and managers? Long-term value creation and top management turnover in hostile and friendly acquirers', British Journal of Management, 17(SUPPL. 1): S7-S30.

Sutherland, P. 2012. Shareholder Democracy in South Africa? In Olaerts, M. \& Schwarz, C.A. Shareholder Democracy: An Analysis of Shareholder Involvement in Corporate Policies. The Hague: Eleven International Publishing.

Trautwein, F. 1990. 'Merger motives and merger prescriptions', Strategic Management Journal, 11: 283-295.

Vasilaki, A. 2009. Enhancing post-acquisition organisational performance: The role of leadership. Unpublished $P h D$ Dissertation. London: Middlesex University.

Weisbach, M.S. 1993. 'Corporate governance and hostile takeovers', Journal of Accounting and Economics, 16(1-3): 199208.

Whate, L.T. 2013. Frustrating action to defend against a hostile bid in South Africa, the UK, the USA and Australia. Unpublished Masters Dissertation University of Cape Town, [online] URL:https://open.uct.ac.za/handle/11427/4578

Wright, P., Kroll, M. \& Elenkov, D. 2002. 'Acquisition returns, increase in firm size and chief executive officer compensation: The moderating role of monitoring', Academy of Management Journal, 45: 599-608.

Yin, R. K. 2003. Case study research. 3rd edition. Thousand Oaks: Sage Publication.

Yin, R.K. 2009. Case study research: Design and methods. In L. Bickman \& D.J. Rog (Eds.) Essential guide to qualitative methods in organizational research (Vol. 5). Thousand Oaks: Sage Publication.

Yin, R.K. 2015. Qualitative research from start to finish. New York: Guilford Publications. 
